\title{
ANALYSIS OF THE EFFECT OF VARIOUS TYPES OF LIMESTONE AS A MAIN CONSTITUENT OF CEMENT ON THE CHOSEN PROPERTIES OF CEMENT PASTES AND MORTARS
}

\author{
J. GOLASZEWSKI ${ }^{1}$, G. CYGAN ${ }^{2}$, M. GOLASZEWSKA ${ }^{3}$
}

\begin{abstract}
The article is an attempt to compare the impact of the use of various types of limestone as the main constituent of cement on selected mortar properties. Four different limestones were added in amount of 15, 30, 40\% to CEM I 42.5 R to obtain limestone cemens. Rheological properties (yield stress, plastic viscosity) of fresh mortar, tensile and compressive mortar strength, early shrinkage, and drying shrinkage were tested. Obtained results indicate that both tensile and compressive strength decreases with the increase of the limestone content in cement. Limestone can worsen or improve workability, depending on distribution of limestone grains. The addition of limestone increases the early shrinkage, but reduces the shrinkage after 28 days. Studies show that the granulation of limestone plays an important role in determining the influence of limestone on mortar properties.
\end{abstract}

Keywords: Limestone; cement mortar; rheology; shrinkage; mechanical properties

\section{INTRODUCTION}

Limestone is widely used in construction, both as a component of cement, and an additive in the production of ready-mix concrete. Good results are achieved by using limestone in the technology of self-compacting concretes, in which it is important to ensure proper rheological properties (as low as possible yield stress and adequate viscosity) ensuring the possibility of self-compacting [1].

\footnotetext{
${ }^{1}$ Prof., DSc., PhD., Eng., Silesian University of Technology, Faculty of Civil Engineering, ul. Akademicka 5, 44-100 Gliwice, Poland, e-mail: jacek.golaszewski@polsl.pl

${ }^{2}$ MSc Eng., Silesian University of Technology, Faculty of Civil Engineering, ul. Akademicka 5, 44-100 Gliwice, Poland, e-mail: grzegorz.cygan@polsl.pl

${ }^{3}$ MSc Eng., Silesian University of Technology, Faculty of Civil Engineering, ul. Akademicka 5, 44-100 Gliwice, e-mail: malgorzata.golaszewska@polsl.pl
} 
However, the addition of limestone to concrete may result in worsened workability [2]. The effect of limestone in the aspect of workability is related to the morphology of its grains [3]. Calcareous stones are easily grindable materials, which is why limestone usually has high specific surface area, what gives great possibilities in shaping viscosity.

The limestone shapes the properties of cement composites through several mechanisms. The first one is the filler effect related mainly to their grain size. In addition, replacing the part of clinker with limestone increases the effective water-cement ratio, as a result of which Portland clinker (cement) grains have more water available for the hydration process [4]. Fine limestone grains also prevent agglomeration of hydration products around clinker grains, and as a result water has easier access to non-hydrated parts of cement grains for a longer period than in the case of Portland cements without the addition of limestone [5]. Fine limestone grains can also act as nucleation agent which accelerate the hydration process, mainly calcium aluminates [6].

Limestone has no pozzolanic or hydraulic properties, and its impact on the compressive strength of cement is small [7]. Generally, compressive strength decreases due to the effect of dilution [8]. This does not mean that the limestone is inert. During the cement hydration process, calcium carbonate from limestone reacts with aluminate phases from the composition of Portland clinker, mainly $\mathrm{C}_{3} \mathrm{~A}$, creating hydrated calcium monocarbonate. [6,9]. Higher amounts of ettringite are also reported [6]. It must be noted, that while there were numerous studies conducted to determine the effect of limestone addition to cement on properties of mortars and cement pastes, the results often are ambiguous, especially in terms of rheological properties of the mortars [4,10,11].

The aim of presented research was to compare the effect of four different limestones as main constituents of cement on chosen properties of cement pastes and mortars.

\section{RESEARCH METHODOLOGY AND MATERIALS}

The research consisted of determination of the influence of limestone addition to cement on the properties of mortars and cement pastes. Part of the cement mass was replaced with 15, 30 and 40\% of limestone. High percentages of limestone were chosen to better showcase possible differences between the limestones. Tests conducted on mortars included the determination of the effect of limestone on consistency (EN 1015-3:2000 [12]), mechanical properties (EN 196-1:2016[13]), rheological properties (yield stress and plastic viscosity) (non-standardized procedure), early shrinkage and drying shrinkage (EN 12617-4:2004 [14]). Initial setting time and water demand were determined on cement pastes (EN 196-3:2016 [15]). Tests of mechanical properties and 
shrinkage were conducted on standard mortars with composition according to EN 196-1:2016 [13], as shown in Table 1. In case of rheological properties and consistency tests, mortar composition was similar to standard mortar, with the exception of w/c ratio, which was increased from 0.5 to 0.55 due to the limitations of the rheometer used in the research.

Table 1. Mortar composition

\begin{tabular}{|c|c|c|c|c|}
\hline \multirow{2}{*}{ Constituent } & \multicolumn{4}{|c|}{ Limestone content [\%] } \\
\cline { 2 - 5 } & 0 & 15 & 30 & 40 \\
\hline CEM I 42,5 R [g] & 450 & 382.5 & 315 & 270 \\
\hline Limestone [g] & 0 & 67.5 & 135 & 180 \\
\hline Water [g] & \multicolumn{5}{|c|}{225} \\
\hline w/c ratio & \multicolumn{5}{|c|}{1350} \\
\hline Standard Sand [g] & \multicolumn{5}{|c}{} \\
\hline
\end{tabular}

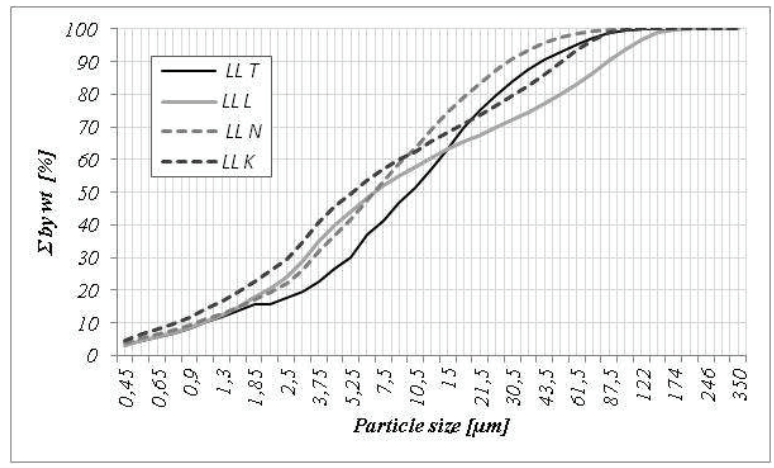

Fig. 1.Particle size distribution of limestones used in the research.

Four different types of limestones were used, all from different producers. Fig. 1 shows the particle size distribution of the limestones. Limestones marked $\mathrm{L}$ and $\mathrm{K}$ are characterised by the high content of coarse fractions and discontinuous particle size distribution, while limestones $\mathrm{N}$ and $\mathrm{T}$ are finer and are characterised by continuous distribution.

The rheological properties of the mortars were tested in the Viskomat NT rheometer, and a simplified Bingham model (Eq. 2.1)was adopted for calculations of the results of the rheometry tests $[16,17]$.

$$
M=g+h N
$$

Where: $\mathrm{M}$ - torque, $\mathrm{N}$ - rotational speed of probe or measuring cylinder, $\mathrm{g}$ - shear resistance, $\mathrm{h}$ plastic flow resistance. In this equation, the shear resistance g corresponds to the yield stress $\tau_{0}$ and the plastic flow resistance $\mathrm{h}$ - plastic viscosity $\eta_{\mathrm{p}}$, and they will be referred as such further. 


\section{EXPERIMENTAL RESULTS}

\subsection{WATER DEMAND AND INITIAL SETTING TIME}

The results of tests of water demand and setting time are shown in tab. 2 .

The addition of limestone reduces the amount of water necessary to obtain a standard consistency, slightly lowering the water demand, however there is no ascertainable difference between the effect of different limestones.

The initial setting time of cement pastes with limestone is faster - in the case of $15 \%$ limestone content it is on average 13 minutes shorter. Increasing the amount of limestone leads to further acceleration of the setting. This effect is more pronounced in the case of finer limestones (limestone $\mathrm{T}$ and $\mathrm{K})$.

The cause for this effect can be connected to the to the nucleation effect. Fine limestone grains work as nucleation seeds, accelerating the hydration process.

Table 2. Water demand and initial setting time of cement pastes with limestones.

\begin{tabular}{|c|c|c|c|c|c|c|c|c|c|c|c|c|c|}
\hline & \multirow{2}{*}{$\sum_{\substack{1 \\
0}}^{\substack{f \\
f}}$} & \multicolumn{3}{|c|}{$\begin{array}{c}\text { CEM I + } \\
\text { Limestone T [\%] }\end{array}$} & \multicolumn{3}{|c|}{$\begin{array}{c}\text { CEM I + } \\
\text { Limestone K [\%] }\end{array}$} & \multicolumn{3}{|c|}{$\begin{array}{c}\text { CEM I + } \\
\text { Limestone N [\%] }\end{array}$} & \multicolumn{3}{|c|}{$\begin{array}{c}\text { CEM I + } \\
\text { Limestone L [\%] }\end{array}$} \\
\hline & & 15 & 30 & 40 & 15 & 30 & 40 & 15 & 30 & 40 & 15 & 30 & 40 \\
\hline $\begin{array}{c}\text { Water } \\
\text { demand }[\%]\end{array}$ & 28,8 & 28,3 & 28,0 & 27,6 & 28,5 & 28,0 & 27,6 & 28,5 & 28,4 & 28,3 & 28,4 & 28,7 & 28,6 \\
\hline $\begin{array}{c}\text { Initial } \\
\text { setting time } \\
{[\mathrm{min}]}\end{array}$ & 204 & 188 & 173 & 170 & 182 & 159 & 163 & 195 & 193 & 172 & 198 & 196 & 195 \\
\hline
\end{tabular}

\subsection{RHEOLOGICAL PARAMETERS AND CONSISTENCY}

The results of rheological tests and consistency tests are shown in tab. 3 and in fig. 2,3. Rheological and consistency tests were conducted on mortars after 5 and 60 minutes from the moment of mixing of the constituents.

The influence of limestone on the rheological properties and the spread diameter of mortar depends on the particle size distribution of the limestone. Addition of limestones $\mathrm{T}$ and $\mathrm{N}$ lowers or does not change the yield stress $\mathrm{g}$ both after 5 and $60 \mathrm{~min}$ after mixing, while addition of limestone L causes an apparent increase. In case of limestone $\mathrm{K}$, the results are inconclusive, as the addition of $15 \%$ of the limestone causes an increase in yield stress, but higher amounts $(30,40 \%)$ slightly decrease the yield stress g.

The positive effect on the consistency of the mortar may be related to continuous granulation of limestones $\mathrm{T}$ and $\mathrm{N}$; limestone $\mathrm{L}$, which clearly increases the yield stress, has a discontinuous, 
coarse graining, and so does, to a lesser extent, limestone K. It should be noted that the consistency differences due to the increasing amount of the limestone, while apparent in case of yield stress $\mathrm{g}$, may not be of practical significance. Testing the flow diameter of the mortar with limestone $\mathrm{L}$ suggests a similar workability as the CEM I reference mortar, while the rheological examination reveals that the yield stress is on average $37 \%$ higher than that of reference mortar. The clear difference in rheological parameters may, however, indicate a worse compatibility with plasticizing admixtures of cements with limestone L, especially seeing as water demand of cements with limestone $\mathrm{L}$ was the highest of all that were tested, however further research is needed.

No clear influence of the increasing amount of limestone in mortar was obtained for the cements with limestone.

Table 3. Rheologcal properties and consistency of mortars with cements with limestone.

\begin{tabular}{|c|c|c|c|c|c|c|c|c|c|c|c|c|c|}
\hline \multirow[t]{2}{*}{ Properties } & \multirow{2}{*}{ 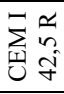 } & \multicolumn{3}{|c|}{$\begin{array}{c}\text { CEM I + } \\
\text { Limestone T }[\%]\end{array}$} & \multicolumn{3}{|c|}{$\begin{array}{c}\text { CEM I + } \\
\text { Limestone K [\%] }\end{array}$} & \multicolumn{3}{|c|}{$\begin{array}{c}\text { CEM I + } \\
\text { Limestone N [\%] }\end{array}$} & \multicolumn{3}{|c|}{$\begin{array}{c}\text { CEM I + } \\
\text { Limestone L [\%] }\end{array}$} \\
\hline & & 15 & 30 & 40 & 15 & 30 & 40 & 15 & 30 & 40 & 15 & 30 & 40 \\
\hline $\begin{array}{c}\text { g after 5, } \\
{[\mathrm{Nmm}]}\end{array}$ & 49,7 & 46,2 & 37,8 & 38,4 & 56,6 & 46,7 & 46,6 & 47,2 & 50,1 & 47,1 & 64,3 & 68,3 & 71,5 \\
\hline $\begin{array}{c}\mathrm{g} \text { after } 60 \\
{[\mathrm{Nmm}]}\end{array}$ & 61,5 & 61,8 & 50,7 & 48,3 & 74,5 & 52,5 & 56,8 & 59,4 & 51,3 & 52,3 & 76,6 & 76,3 & 78,8 \\
\hline $\begin{array}{l}\mathrm{h} \text { after 5, } \\
{[\mathrm{Nmms}]}\end{array}$ & 12,4 & 11,7 & 11,9 & 13,3 & 12,8 & 12,1 & 12,0 & 10,2 & 10,7 & 10,9 & 11,6 & 11,3 & 10,8 \\
\hline $\begin{array}{c}\text { h after 60' } \\
{[\mathrm{Nmms}]}\end{array}$ & 11,6 & 11,6 & 12,8 & 13,6 & 12,5 & 12,7 & 12,9 & 10,6 & 11,2 & 11,7 & 11,5 & 11,9 & 11,1 \\
\hline $\begin{array}{c}\text { Flow } \\
\text { diameter } \\
\text { after 5' }[\mathrm{cm}]\end{array}$ & 20,0 & 21,5 & 21,7 & 22,6 & 20,9 & 21,4 & 21,3 & 20,9 & 20,7 & 20,5 & 20,0 & 19,2 & 20 \\
\hline $\begin{array}{c}\text { Flow } \\
\text { diameter } \\
\text { after } 60 \text { ' } \\
{[\mathrm{cm}]}\end{array}$ & 19,9 & 20,2 & 20,9 & 21,5 & 20,6 & 20,4 & 20,8 & 20,2 & 19,7 & 20,4 & 19,2 & 19,5 & 19,5 \\
\hline
\end{tabular}
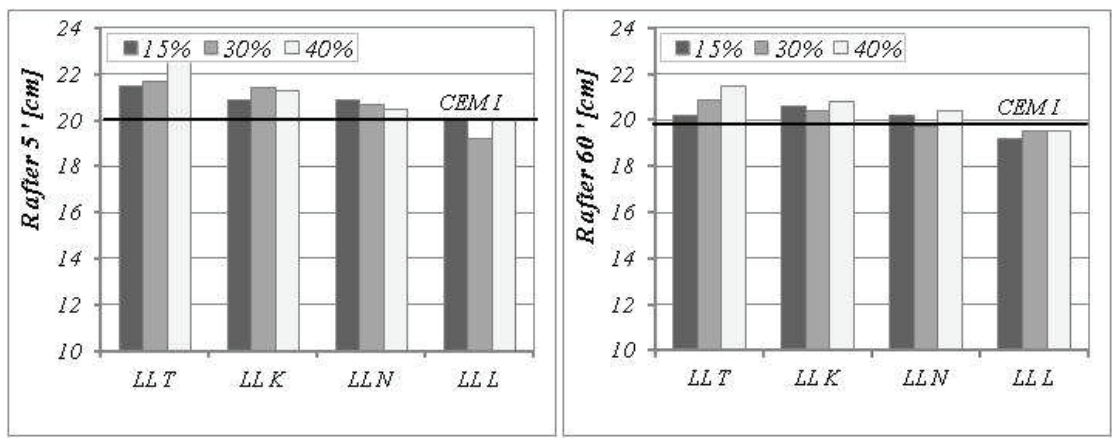

Fig. 2. Influence of limestone content on the flow diameter after 5 and 60 min after mixing. 


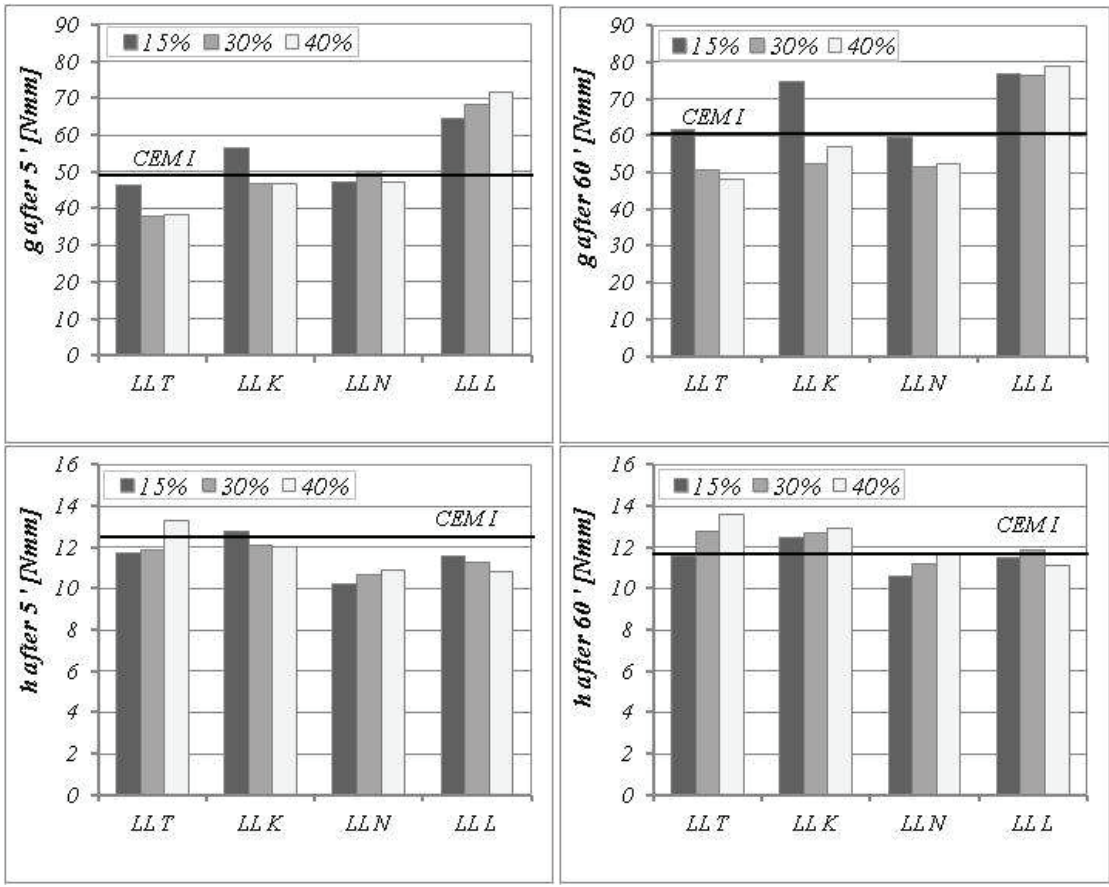

Fig. 3. Influence of limestone content on the rheological properties after 5 and 60 min after mixing.

\subsection{MECHANICAL PROPERTIES}

The tensile and compressive strength of mortar is reduced as the amount of limestone increases (fig. 4). Limestone is a mostly inert addition to cement, that does not form any phases which would influence the strength in a manner similar to products of clinker hydration, and thus with the increase in limestone content, strength decreases. The filler effect of limestone in the cement paste structure is not able to reduce the negative impact of replacing clinker at the $15-40 \%$ of limestone addition.

All limestones exhibited similar effect on strength of mortars, however it must be noted, that cements with limestone $\mathrm{N}$ were characterised by the lowest decrease in strength, especially for higher contents of limestone. It might be related to the continuous particle size distribution with a high content of fine grains, as this grading can lead to decreased porosity of the cement paste [18]. 

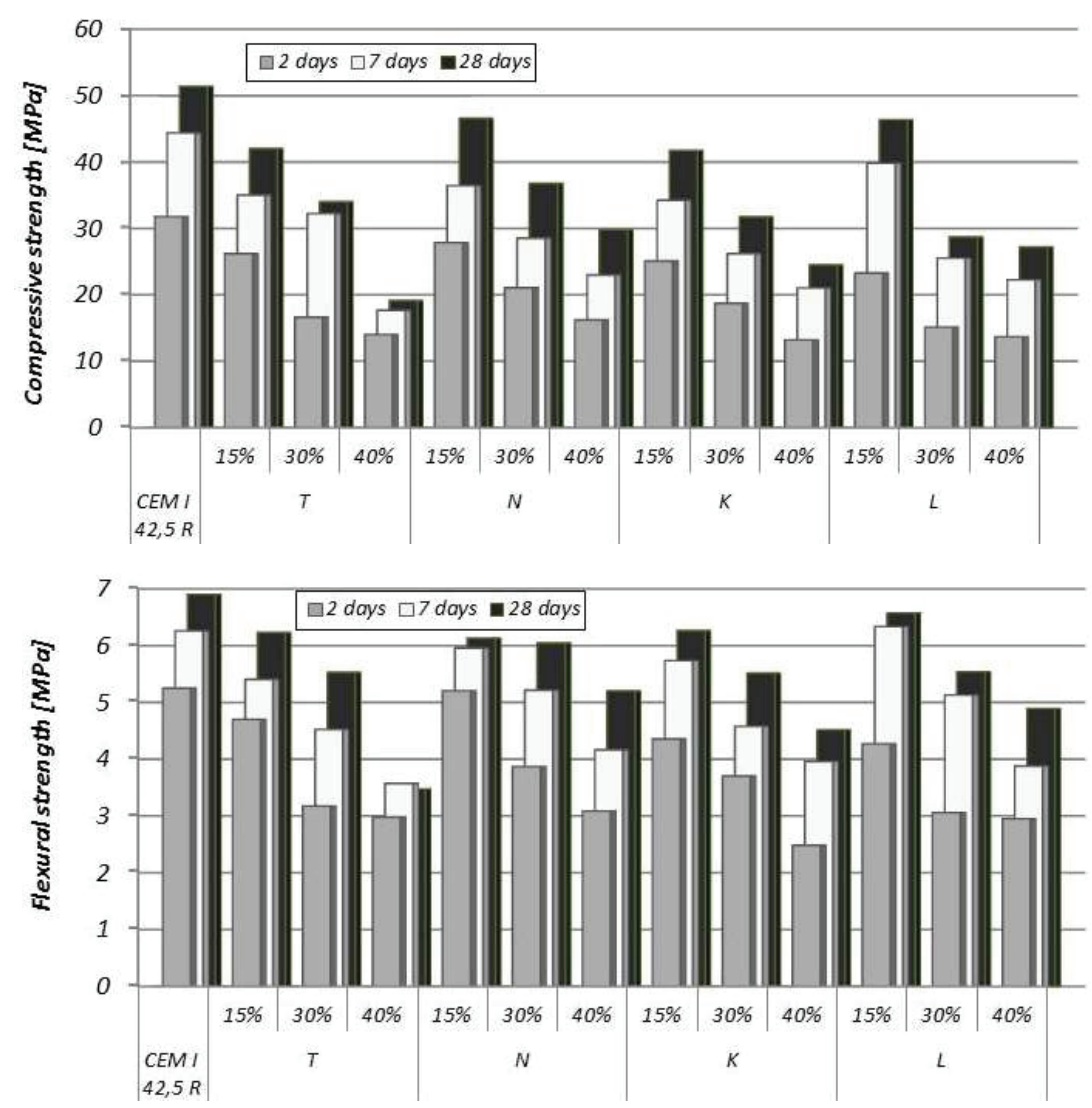

Fig.4. Tensile and compressive strength of mortars after 2, 7 and 28 days

Compressive strength decrease is not proportional to the amount of clinker substitution, especially in case of high limestone content. For all tested limestones, strength of mortars with $40 \%$ limestone after 2, 7 and 28 days was between $40 \%$ and $50 \%$ of strength of Portland cement, while for mortars with $30 \%$ limestone content $-50-70 \%$, and for mortars with $15 \%$ limestone content $-80-90 \%$.

\subsection{EARLY AND DRYING SHRINKAGE}

The early shrinkage was determined on 40x40x160 mm beams, the measurement was carried out in modified TLS system, which general idea was presented in [19]. The system allows to measure changes in sample length from the moment of forming, by laser distance measurement on one end of the sample. The method of sample preparation ensures minimization of friction forces between the mortar and the walls of the form. 
Limestone increases shrinkage in the first 24 hours. This may be due to the increase in the volume of cement paste, which is related to the difference in the density of limestone and cement. By replacing the bulk of the cement with limestone of lower density, the total volume of limestone powder and cement is higher, and thus, the volume of the phase undergoing shrinkage is larger. The limestone may reduce the capillary pore diameter (by the filler effect) which increases the shrinkage strain. The shrinkage is directly proportional to the capillary forces, the size of which is the higher, the smaller the diameter of the capillary pores. Mortars with limestone $\mathrm{N}$ with fine grain size, which can reduce the capillary pore diameter, are characterized by the greatest early shrinkage.

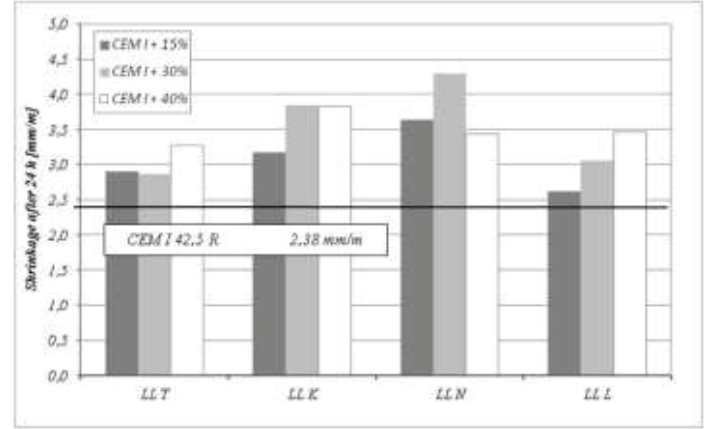

Fig.5. Early shrinkage of mortars with cement with $15,30,40 \%$ of limestone after 24 hours

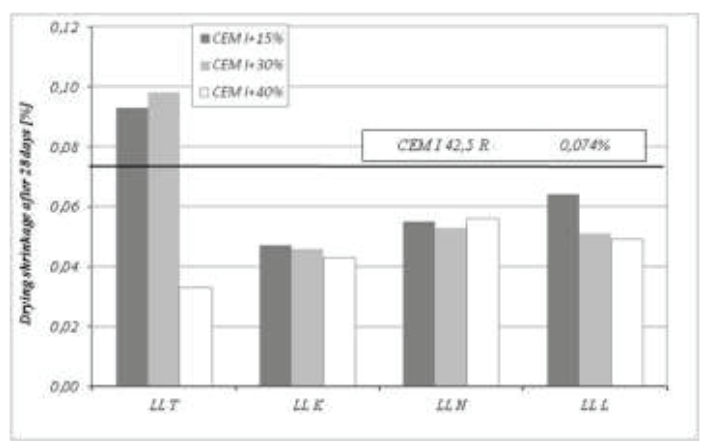

Fig.6. Drying shrinkage of mortars with cement with $15,30,40 \%$ of limestone after 28 days

In terms of drying shrinkage observed on day 28, the reverse effect is visible - mortar with limestone undergoes less shrinkage deformations, except mortars with 15 and $30 \%$ of limestone L (fig. 5). This may be due to the appearance of hydration products of an expansive nature. According to [6] in the cement paste with the addition of limestone, the amount of ettringite remains constant at the later periods of hydration, and additionally calcium monocarbonate appears instead of monosulphate, which may lower the porosity of the structure of cement paste limiting capillary 
porosity [20]. A significant reduction in drying shrinkage after day 28 in case of mortar with limestone powder (Fig.6) may indicate the appearance of an expansive compound in the mortar, which led to compensation of shrinkage, but at the same time led to a significant reduction in the 28-day compressive strength of this mortar.

\section{CONCLUSIONS}

Conducted tests of mortars with cement with limestone in an amount of $15-40 \%$ of cement mass lead to the following conclusions:

- The addition of $40 \%$ limestone causes a drop in strength by approx. $50 \%$ compared to reference mortar, what is related to the grain size. Compressive strength decrease is not proportional to the amount of clinker substitution, especially in case of high limestone content.

- Limestone $\mathrm{N}$ exhibited the highest compressive and tensile strength, while limestone $\mathrm{T}$ - the lowest. With the exeption of limestone $\mathrm{T}$, all limestones reached similar ensile strength.

- The consistency and yield stress of mortars from limestone cements are related to grain size distribution - limestones with a continuous distribution improve consistency and reduce or do not change the yield stress. Limestone with bimodal distribution increased or did not change the flow limit and deteriorated consistency.

- Cement limestones with a high content of fine grains were characterized by a shorter start of setting time. Cements with limestone with a coarse grain size had a similar start time. The water demand of cement with the addition of limestone is lower than that of Portland cements for all tested cements

- Addition of limestone to cement increases the shrinkage of the early mortar, but reduces shrinkage after 28 days. The effect is similar for all tested cements.

\section{REFERENCES}

1. R. Derabla, M. L., Benmalek, "Characterization of heat-treated self-compacting concrete containing mineral admixtures at early age and in the long term". Construction and Building Materials, 66, 787-794, 2014.

2. S.A. Rizwan, T.A. Bier, "Blends of limestone powder and fly-ash enhance the response of self-compacting mortars" Construction and Building Materials 27, 398-403, 2012

3. B. Felekoglu, "Utilisation of high volumes of limestone quarry wastes in concrete industry (self-compacting concrete case)" Resources, Conservation \& Recycling, 51, 770-791, 2007

4. P., Boos, R., Haerdtl, "Experience report Portland limestone cement", 2004.

5. A.R. Mohamed, M. Elsalamawy, M. Ragab, "Modeling the influence of limestone addition on cement hydration", Alexandria Engineering Journal, 54, 1-5, 2015

6. B. Lothenbach, G. Le Saout, E. Gallucci, K. Scrivener, "Influence of limestone on the hydration of Portland cements", Cement and Concrete Research 38, 848-860, 2008. 
7. A.M. Diab, A.E.M.A. Elmoaty, A.A. Aly, "Long term study of mechanical properties, durability and environmental impact of limestone cement concrete", Alexandria Engineering Journal, 55, 1465-1482, 2016

8. A.A. Ramezanianpour, E. Ghiasvand, I. Nickseresht, M. Mahdikhani, F. Moodi, "Influence of various amounts of limestone powder on performance of Portland limestone cement concretes" Cement and Concrete Composites, 31, 715-720, 2009

9. K. Celik, C. Meral, A.P. Gursel, P. Kumar Mehta, A. Horvath, P.J.M. Monteiro, "Mechanical properties, durability, and life-cycle assessment of self-consolidating concrete mixtures made with blended portland cements containing fly ash and limestone powder", Cement and Concrete Composites, 56, 59-72, 2015

10. L. Courard, D. Herfort, Y. Villagran, "Raport: Performances of limestone modified Portland cement and concrete", RILEM, 2016

11. M. Piechówka, Z. Giergiczny, (2011). „Wpływ kamienia wapiennego na właściwości reologiczne zaczynu cementowego" Budownictwo, Technologie, Architektura, 1, 58-61, 2011.

12. European standard EN 1015-3:2000 Methods of test for mortar for masonry. Determination of consistence of fresh mortar (by flow table)

13. European standard EN 196-1:2016: Methods of testing cement. Determination of strength

14. EN 12617-4:2004 Products and systems for the protection and repair of concrete structures. Test methods. Determination of shrinkage and expansion.

15. EN 196-3:2016: Methods of testing cement. Part 3, Determination of setting times and soundness.

16. N. Roussel, "Understanding the rheology of concrete", Woodland, 2011.

17. G. Tattersall, P. F. G. Banfill. The Rheology of Fresh Concrete, Pitman Books Limited, Boston 1983

18. L. Courard, F. Michel, "Limestone fillers cement based composites: Effects of blast furnace slags on fresh and hardened properties", Construction and Building Materials, 51, 439-445, 2014

19. J. Gołaszewski, T. Ponikiewski, G. Cygan, M. Gołaszewska, ,Laser System for Testing Early Shrinkage of Concrete Elements" Transactions of the VŠB, 16(2), 25-34. 2016

20. S. Chłądzyński, A. Garbarcik, „Cementy wieloskładnikowe w budownictwie” Stowarzyszenie Producentów Cementu, Kraków. 2008 (in Polish)

\section{LIST OF FIGURES AND TABLES:}

Tab. 1. Mortar composition

Tab. 1. Składy zapraw

Tab. 2. Water demand and initial setting time of cement pastes with limestones.

Tab. 2. Wodożądność i początek czasu wiązania zaczynów cementowych z wapieniem

Tab. 3. Rheologcal properties and consistency of mortars with cements with limestone.

Tab. 3. Właściwości reologiczne i konsystencja zapraw z cementami z wapieniem

Fig. 1. Particle size distribution of limestones used in the research.

Fig. 1. Rozkład uziarnienia wapieni zastosowanych w badaniach.

Fig. 2. Influence of limestone content on the flow diameter after 5 and 60 min after mixing.

Fig. 2. Wpływ zawartości wapienia na średnicę rozpływu po 5 i 60 min po zmieszaniu składników

Fig. 3. Influence of limestone content on the rheological properties after 5 and 60 min after mixing.

Fig. 3. Wpływ zawartości wapienia na właściwości reologiczne po 5 i 60 min po zmieszaniu składników

Fig.4. Tensile and compressive strength of mortars after 2, 7 and 28 days

Fig.4. Wytrzymałość na zginanie i ściskanie po 2, 7 i 28 dniach

Fig.5. Early shrinkage of mortars with cement with 15, 30, 40\% of limestone after 24 hours

Fig.5. Wczesny skurcz po $24 \mathrm{~h}$ zapraw z cementami z 15, 30, 40\% wapienia

Fig.6. Drying shrinkage of mortars with cement with $15,30,40 \%$ of limestone after 28 days

Fig.6. Skurcz wysychania po 28 dniach zapraw z cementami z 15, 30, 40\% wapienia 


\section{ANALIZA WPLYWU RÓŻNYCH RODZAJÓW WAPIENIA JAKO SKLADNIKA GLÓWNEGO CEMENTU NA WYBRANE WLAŚCIWOŚCI ZACZYNÓW I ZAPRAW}

Keywords: Wapień, cement, zaprawa, reologia, skurcz, właściwości mechaniczne

\section{SUMMARY:}

Mączki wapienne są stosowane szeroko w budownictwie, między innymi jako składnik główny cementu. Mączki wapienne kształtują właściwości kompozytów cementowych poprzez kilka mechanizmów.

Pierwszym jest efekt wypełnienia związany głównie z ich uziarnieniem. Oprócz tego zastąpienie części klinkieru wapieniem powoduje wzrost efektywnego stosunku wodno-cementowego, w efekcie czego ziarna klinkieru portlandzkiego (cementu) mają dostępne więcej wody do procesu hydratacji. Drobne ziarna wapienia zapobiegają także aglomeracji produktów hydratacji wokół ziaren klinkieru, w efekcie woda ma łatwiejszy dostęp do niehydratyzowanych części ziaren cementu przez dłuższy okres niż w przypadku cementów portlandzkich bez dodatku wapienia. Drobniejsze od klinkieru ziarna wapienia mogą także działać jako zarodki krystaliczne, które przyspieszają proces hydratacji, w głównej mierze glinianów wapniowych.

Wapień nie ma właściwości pucolanowych czy hydraulicznych, a jego wpływ na wytrzymałość na ściskanie cementu jest niewielki. Generalnie wytrzymałość na ściskanie zmniejsza się co jest związane z efektem rozcieńczenia.

Wpływ wapienia na niektóre właściwości cementów wapiennych, m.in. czas wiązania oraz właściwości reologiczne, jest jednak niejednoznaczny. Celem przeprowadzonych badań było więc sprawdzenie jak różne rodzaje wapienia wpływają na wybrane właściwości zaczynów i zapraw z cementem z wapieniem jako składnikiem głównym.

Badania obejmowały określenie wpływu dodatku mączek wapiennych na właściwości zapraw i zaczynów. Część cementu zastępowano masowo mączką wapienną w ilości 15, 30 i 40 \%. Na zaprawach określono wpływ mączek na konsystencję (PN-EN 1015-3), właściwości reologiczne i skurcz wczesny (procedury nie standaryzowane), skurcz wysychania (PN-EN12617-4) i właściwości mechaniczne (PN-EN 196-1). Czas początku wiązania i wodożądność określono na zaczynach cementowych (PN-EN 196-3). Badania właściwości mechanicznych skurczu wczesnego i wysychania były wykonane dla zapraw o składach jak zapraw normowych. W przypadku badań właściwości reologicznych i konsystencji podwyższono stosunek w/c z 0,5 na 0,55, z uwagi na ograniczenia wynikające z możliwości pomiarowych.

Dodatek mączek wapiennych zmniejsza ilość wody niezbędną do uzyskania konsystencji normowej.

Czas początku wiązania zaczynów z wapieniem następuje szybciej, w przypadku $15 \%$ zamiany cementu mączką jest to średnio o 13 minut wcześniej. Zwiększanie ilości mączki prowadzi do dalszego przyspieszenia początku wiązania. Efekt ten jest wyraźniejszy w przypadku mączek o ciągłym drobniejszym uziarnieniu (wapień T i K) Dodatek wapienia może skracać czas wiązania dzięki efektowi nukleacji, czyli działaniu drobnych ziaren wapienia jako zarodków krystalizacji.

Wpływ mączek wapiennych na właściwości reologiczne i średnicę rozpływu zapraw jest zależny od uziarnienia mączki. Mączki T, K, i N sprawiają, że średnica rozpływu zapraw się zwiększa a granica płynięcia i lepkość się zmniejsza. Pozytywny wpływ na konsystencję zapraw może mieć związek z ich drobniejszym uziarnieniem Mączka L, która wyraźnie zwiększa granicę płynięcia ma nieciągłe najgrubsze uziarnienie. Wpływ zwiększającej się ilości mączki w zaprawie nie da się uogólnić, bo możliwy jest zarówno wzrost średnicy rozpływu jak i jej zmniejszenie. Należy zaznaczyć, że różnice w konsystencji spowodowane zwiększającą się ilością mączek T, K i N są niewielkie. 
Wytrzymałość na rozciąganie i ściskanie zapraw ulega zmniejszeniu wraz ze wzrostem ilości mączki wapiennej. Zwiększenie ilości mączki wapiennej sprawia, że porowatość matrycy wzrasta (wzrost stosunku w/c), zwiększa się udział fazy inertnej, która nie wprowadza więzów kształtujących wytrzymałość zaprawy.

Sam efekt doszczelnienia struktury zaczynu bez powiązania cząstek wapienia za pomocą wiązań chemicznych nie jest w stanie zmniejszyć negatywnego odziaływania mączek wapiennych. Pojawiający się w późniejszym okresie etryngit może również prowadzić do rozluźnienia struktury zaprawy, co może być powodem wyraźnego zmniejszenia wytrzymałości na ściskanie po 28 dniach dojrzewania zapraw z mączką T. Mączka N o ciągłym drobnym uziarnieniu w najmniejszym stopniu zmniejsza wytrzymałość na ściskanie, co może być związane z tym że lepiej doszczelnia strukturę zaprawy.

Skurcz wczesny określono na beleczkach 40×40×160 mm, pomiar był realizowany za pomoca modyfikacji system TLS. Pozwala określać zmiany długości próbek począwszy od momentu zaformowania próbki. Zasada działania oparta jest na laserowym pomiarze odległości. Metodyka przygotowania próbki zapewnia minimalizację sił tarcia pomiędzy zaprawą a ściankami formy. Mączki wapienne zwiększają odkształcenia skurczowe zachodzące w pierwszych 24 godzinach. Może to być spowodowane wzrostem objętości zaczynu, który jest związany z różnicą gęstości mączek wapiennych i cementu. Zastępując masowo część cementu mączką wapienną o mniejszej gęstości objętość sumaryczna mączki wapiennej i cementu będzie większa. Większa tym samym będzie objętość fazy ulegającej skurczowi, co thumaczy wzrost skurczu w 24 godzinie od zaformowania.

Zaprawy z mączką N o ciągłym najdrobniejszym uziarnieniu, które może zmniejszać średnicę porów kapilarnych zaprawy charakteryzują się największym skurczem wczesnym. W aspekcie skurczu wysychania obserwowanego w 28 dniu widoczny jest efekt odwrotny, zaprawy z mączkami wapiennymi ulegają mniejszym odkształceniom skurczowym, poza zaprawami z 15 i $30 \%$ mączki L. Być może jest to związane z pojawieniem się produktów hydratacji o ekspansywnym charakterze np. etryngitu.

Przeprowadzone badania zapraw z cementami z wapieniem w ilości 15-40\% masy cementu prowadzą do następujących wniosków:

- Zarówno wytrzymałość na zginanie, jak i na ściskanie zmniejsza się wraz ze wzrostem zawartości wapienia w zaprawie. Dodatek 40\% wapienia powoduje spadek wytrzymałości o ok. 50\% w stosunku do zapraw z cementu portlandzkiego. Wytrzymałość na ściskanie i zginanie może być zależna od wielkości uziarnienia.

- Konsystencja i granica płynięcia zapraw z cementów z wapieniem jest związana z rozkładem uziarnienia wapienie o ciągłym, symetrycznym lub umiarkowanie symetrycznym rozkładzie poprawiały konsystencję oraz zmniejszały lub nie zmieniały granicy płynięcia. Wapienie o rozkładzie bimodalnym zwiększały lub nie zmieniały granicę płynięcia i pogarszały konsystencję.

- Wodożądność cementów z dodatkiem wapienia jest niższa od wodożądności cementów portlandzkich.

- Zaczyny cementowe z wapieniem o dużej zawartości drobnych ziaren charakteryzowały się krótszym czasem początku wiązania. Cementy z wapieniem o grubym uziarnieniu miały podobny czas początku wiązania.

- Dodatek wapienia do cementu podwyższa skurcz wczesny zapraw, ale obniża skurcz wysychania po 28 dniach.

Received 15.04.2019, Revised 30.04.2019 